\title{
Interaction Studies of a Novel, Water-Soluble and Anti-Cancer Palladim(II) Complex with Calf Thymus DNA
}

\author{
H. Mansouri-Torshizi, ${ }^{*}$ M. Saeidifar, A. Divsalar, ${ }^{\dagger}$ A. A. Saboury, ${ }^{\ddagger}$ and S. Shahraki \\ Department of Chemistry, University of Sistan and Baluchestan, Zahedan, Iran. *E-mail: hmtorshizi@hamoon.usb.ac.ir \\ ${ }^{\dagger}$ Department Of Biological Sciences Tarbiat Moallem University Tehran, Iran \\ ${ }^{\ddagger}$ Institute of Biochemistry and Biophysics, University of Tehran, Tehran, Iran \\ Received November 9, 2009, Accepted January 4, 2010
}

\begin{abstract}
We report the preparation and characterization of a new and water soluble complex of palladium(II) with 1,10- phenanthroline and butyldithiocarbamate ligands. This compound has been studied through spectroscopic techniques, ${ }^{1} \mathrm{H}$ NMR, IR, electronic spectra and elemental analysis and conductivity measurements. The complex shows $50 \%$ cytotoxic concentration $\left(\mathrm{Ic}_{50}\right)$ value against chronic myelogenous leukemia cell line, K562, much lower than that of cisplatin. Thus the mode of binding of this complex to calf thymus DNA have been extensively investigated by isothermal titration UV-visible spectrophotometry, fluorescence, gel filteration and other methods. UV-visible studies show that the complex exhibits cooperative binding with DNA and remarkably denatures the DNA at extremely low concentration $(\sim 13$ $\mu \mathrm{M})$. Fluorescence studies indicate that the complex intercalate into DNA. Gel filtration studies suggest that the binding of $\mathrm{Pd}(\mathrm{II})$ complex with DNA is strong enough that it does not readily break. In these interaction studies, several thermodynamic and binding parameters are also determined which may reflect the mechanism of action of this type of compound with DNA.
\end{abstract}

Key Words: DNA-binding, Palladium(II) complex, Cytotoxicity, 1,10-Phenanthroline, Dithiocarbamate

\section{Introduction}

The design of small transition metal complexes that can interact at specific sequences of DNA is an important research line. ${ }^{1-3}$ There are several types of binding sites on DNA where binding of metal complexes can occur: (i) covalent binding with purine and pyrimidine bases, (ii) intercalation between base pairs, (iii) in the minor groove, (iv) in the major groove, (v) hydrogen binding with different groups, (vi) ionic binding mainly with phosphate groups, (vii) hydrophobic and hydrophilic interactions ${ }^{4,5}$ etc. Moreover, several biological experiments have also suggested that the DNA is the biological target of many antitumor drugs and potential antineoplastic agents. ${ }^{6,7}$

Many classes of currently used pharmaceutical agents contain examples of metal compounds. Typical examples of anticancer drugs are cisplatin, oxaliplatin, nedaplatin and carboplatin. ${ }^{8}$ Today, cis-diamminedichloroplatinum(II) (cisplatin) is one of the most effective drugs used to treat urogenital tumors, head, neck, small cell lung and cervical carcinomas. ${ }^{9}$ Other transition metal complexes with favorable antitumor activity are rhodium and palladium complexes. ${ }^{10}$ However, a serious difficulty with cisplatin as an anticancer drug is its toxicity towards the kidney. ${ }^{11,12}$ This problem can be reduced to a tolerable level if the flow of urine is greatly increased by the simultaneous administration of water and diuretic drugs, or by the use of other drugs in combination with cisplatin. ${ }^{13}$ In response to this need one approach has used diethyldithiocarbamate in combination with cisplatin. Because it has protected a variety of animal species from renal, gastrointestinal and bone marrow toxicity, induced by cisplatin. ${ }^{14}$ However, several platinum and palladium dithiocarbamate complexes are known to have been tested in various medical applications. ${ }^{15-19}$ In these complexes, the major advantage of us- ing the small bite-angle of dithiocarbamate moiety as a stabilizing chelating ligand is its unique property to remain intact under a variety of reaction conditions. ${ }^{20}$

Recently we have reported several dithiocarbamate derivatives of 2,2'-bipyridine-platinum(II)/-palladium(II) complexes. $^{21-23}$ These complexes have shown antitumor activity much lower than that of cisplatin against human cell tumor line, K562, in vitro. They intercalate in DNA; hence the biological target molecule of these complexes seems to be DNA of the cell. Moreover, these complexes have good water solubility and they are expected to have low toxicity due to their inability to bind sulfhydryl groups of proteins of kidney tubules.

We have now extended our efforts and prepared butyldithiocarbamato1,10-phenanthrolinepalladium(II) nitrate to see the changes in its properties such as cytotoxicity, binding and thermodynamic parameters. In this complex, the coplanarity of 2,2'bipyridine has been extended by replacing it with 1,10-phenanthroline which may influence the intercalation properties of this complex. Using electronic absorption, fluorescence titration and gel filtration experiments, the mode of binding of the complex to DNA were studied in detail and the results of these investigations are reported here. The information obtained from this study will be helpful to understand the mechanism of the interaction between this agent and nucleic acid. This mechanism must be different from that reported for cisplatin.

\section{Experimental}

Materials and general methods. The reagents and solvents were of analytical grade. Butylamine and $\mathrm{AgNO}_{3}$ were purchased from Aldrich (England)., Tris-HCl buffer, 1,10-phenanthroline, $\mathrm{CS}_{2}, \mathrm{NaOH}, \mathrm{NaCl}$ and $\mathrm{KBr}$ were obtained from Merck 
(Germany). Palladium(II) chloride anhydrous was bought from Fluka (Switzerland) and highly polymerized calf thymus DNA sodium salt from Sigma Chemical Co. (U.S.A.). The ligand butyldithiocarbamate sodium salt ( $\mathrm{Bu}$-dtc $\mathrm{Na}$ ) was synthesized as reported earlier. ${ }^{22}\left[\mathrm{Pd}(\mathrm{phen}) \mathrm{Br}_{2}\right]$ was prepared by the procedure described in the literature. ${ }^{22}$

Infrared spectrum of the metal complex was recorded on a $\mathrm{J}_{\mathrm{AS} . \mathrm{CO}}-460$ Plus FT-IR spectrophotometer in the range of 4000 $400 \mathrm{~cm}^{-1}$ in $\mathrm{KBr}$ pellets. Electronic absorption spectrum of the title metal complex was measured on a $\mathrm{J}_{\mathrm{AS} . \mathrm{CO}} \mathrm{UV} / \mathrm{vis}-7850$ recording spectrophotometer. ${ }^{1} \mathrm{H}-\mathrm{NMR}$ spectra were recorded on a Brucker DRX-500 Avance spectrometer at $500 \mathrm{MHz}$ in DMSO- $d_{6}$ using tetramethylsilane as internal reference. Conductivity measurements of the above Palladium complex was carried out on a Systronics conductivity bridge 305, using a conductivity cell of cell constant 0.98 . Microchemical analysis of carbon, hydrogen and nitrogen for the complex was carried out on a Herause CHNO-RAPID elemental analyzer. Melting points were measured on a Unimelt capillary melting point apparatus and reported uncorrected. Doubly distilled water was used as solvent.

Synthesis of butyldithiocarbamato-1,10-phenanthrolinepalladium(II) nitrate [Pd(Bu-dtc)(phen)] $\mathbf{N O}_{3}$. This complex was synthesized by the procedure described previously, ${ }^{22}$ except that [Pt(bpy)Cl $\mathrm{Cl}_{2}$ ] was replaced by $[\mathrm{Pd})($ phen $\left.) \mathrm{Br}_{2}\right](0.45 \mathrm{~g}, 1 \mathrm{mmol})$. The yield was $0.317 \mathrm{~g}, 64 \%$ and the complex decomposes at 174 ${ }^{\circ} \mathrm{C}$. Analysis calculated for $\mathrm{C}_{17} \mathrm{H}_{18} \mathrm{~N}_{4} \mathrm{O}_{3} \mathrm{~S}_{2} \mathrm{Pd}$ (496): C, 41.13; H, 3.63; N, 11.29\%. Found: C, 41.09; H, 3.64; N, 11.31\%. Solid state FT-IR spectroscopy of the above complex shows three main characteristic stretching bands at 1560, 1034 and 3220 $\mathrm{cm}^{-1}$ assigned to $v(\mathrm{~N}-\mathrm{CSS}), v(\mathrm{SCS})$ and $(\mathrm{N}-\mathrm{H})$ modes respectively. ${ }^{24,25}$ The sharp band at $1386 \mathrm{~cm}^{-1}$ is assigned to uncoordinated $\mathrm{NO}_{3}{ }^{-}$anion. ${ }^{26}$ Electronic spectra exhibit four bands. The band at $354(\log \varepsilon=3.55)$ assigned to MLCT and the other bands at $273(\varepsilon=4.50), 245(\varepsilon=4.58)$ and $210(\varepsilon=4.73)$ may be assigned to first, second and higher intraligand $\pi-\pi^{*}$ transitions of 1,10 phenanthroline ligand as well as - $\mathrm{CSS}^{-}$group of dithiocarbamate. ${ }^{1} \mathrm{H}$ NMR $\left(500 \mathrm{MHz}, \mathrm{DMSO}-d_{6}\right.$, ppm, sb = singlet broad, $\mathrm{t}=$ triplet and $\mathrm{m}=$ multiplet): $0.96(\mathrm{t}, 3 \mathrm{H}, \mathrm{H}-\mathrm{a}), 1.39(\mathrm{~m}, 2 \mathrm{H}$, H-b), 1.61 (m, 2H, H-c), 3.42 (m, 2H, H-d), 11.54 (sb, -NH-), 7.88 (m, 2H, H-3,8), 8.06 ( sb, 2H, H-5,6), 8.28 (m, 2H, H-4,7), 8.78 (m, 2H, H-2,9) (Scheme 1 (II)). Molar conductance measurement for the complex is $94.16 \Omega^{-1} \mathrm{~mol}^{-1} \mathrm{~cm}^{2}$ indicating $1: 1$ electrolyte. $^{27}$

Cytotoxic studies. The method followed has been reported previously. ${ }^{28}$ Here also $1 \times 10^{4}$ cells $/ \mathrm{mL}$ of chronic myelogenous leukemia cell line $\mathrm{K} 562$ were used in Tris- $\mathrm{HCl}$ buffer solution of $\mathrm{pH} 7.0$ and all experiments were carried out in triplicates.

Binding studies. $[\mathrm{Pd}(\mathrm{Bu}-\mathrm{dtc})($ phen $)] \mathrm{NO}_{3}$ complex was interacted with calf thymus DNA in Tris-HCl buffer $(10 \mathrm{mM}$ of $\mathrm{pH}$ 7.0) containing $10 \mathrm{mM}$ sodium chloride using the ultraviolet absorption and fluorescence techniques as reported earlier. ${ }^{21}$ Palladium complex $(0.05 \mathrm{mmol} / \mathrm{L})$ were made in Tris- $\mathrm{HCl}$ buffer by gentle stirring and heating at $35^{\circ} \mathrm{C}$, while that of DNA (4 $\mathrm{mg} / \mathrm{mL}$ ) at $4{ }^{\circ} \mathrm{C}$ until homogenous. All the spectrophotometric measurements were done at $\lambda_{\max }$ of Pd(II) complex (300 nm) where DNA has no absorption. In these studies, the metal complex and DNA were incubated in Tris- $\mathrm{HCl}$ buffer at $300 \mathrm{~K}$ and

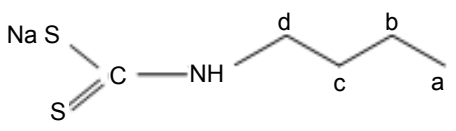

(I)

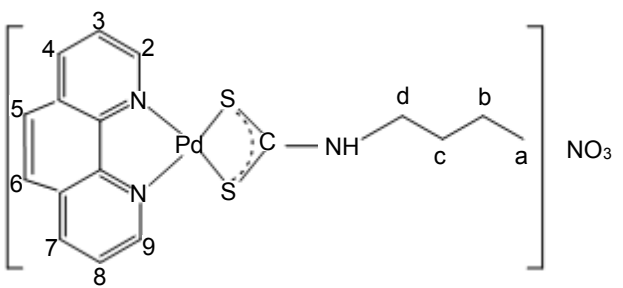

(II)

Scheme 1. Proposed structure and nmr numbering schemes of (I) Bu$\mathrm{dtcNa}$ and (II) $\left[\mathrm{Pd}(\mathrm{Bu}-\mathrm{dtc})(\mathrm{phen}) \mathrm{NO}_{3}\right.$

$310 \mathrm{~K}$ for $6 \mathrm{~h}$ before spectral measurements. Because using trial and error method, the incubation time for solutions of DNAmetal complex was found to be $6 \mathrm{~h}$ at $300 \mathrm{~K}$ as well as $310 \mathrm{~K}$. No further changes were observed in the absorbance readings after longer incubation indicating that the reaction is completed. The concentration of DNA was found out based on determination of phosphate $(\mathrm{P})$. Millimolar extinction coefficient of native DNA solution at $\lambda_{258}$ based on DNA P was $6.6 \times 10^{3} \mathrm{M}^{-1} \mathrm{~cm}^{-1}$.

\section{Results and Discussion}

A new palladium(II) complex of general formula [Pd(Bu-dtc) (phen) $\mathrm{NO}_{3}$ (where Bu-dtc is an anion of butyldithiocarbamate and phen is 1,10-phenanthroline) has been synthesized by interaction of $\left[\mathrm{Pd}(\mathrm{phen})\left(\mathrm{H}_{2} \mathrm{O}\right)_{2}\right]\left(\mathrm{NO}_{3}\right)_{2}$ with an anion of butyldithiocarbamate. The analytical data of this complex are given in experimental section and the proposed structures in scheme 1. Cytotoxicity and the modes of binding of this complex to CTDNA have been studied:

Cytotoxicity results. The above palladium(II) complex has been tested against K562 leukemia cells ${ }^{22}$ and its 50\% inhibitory dose $\left(\mathrm{Ic}_{50}\right)$ value is $10 \mu \mathrm{M}$ (Fig. 1). Ic $\mathrm{C}_{50}$ value of cisplatin, the well known anticancer drug, under the same experimental conditions was determined. These growth inhibition studies show that $\mathrm{Ic}_{50}$ value of $[\mathrm{Pd}(\mathrm{Bu}-\mathrm{dtc})(\mathrm{phen})] \mathrm{NO}_{3}$ complex is around fifteen times less than cisplatin, $(154 \mu \mathrm{M})$.

It is also lower than our analogous $\mathrm{Pd}$ (II) dithiocarbamate complexes reported earlier. ${ }^{22}$ The growth inhibition studies of the metal complex suggested that the DNA is the target biomacromolecule for this complex as well as cisplatin. ${ }^{30}$

UV-vis spectral studies and evaluation of binding parameters. Various concentrations of CT-DNA (66.8 to $283.9 \mu \mathrm{M}$ for the experiments carried out at $300 \mathrm{~K}$ and 37.2 to $558 \mu \mathrm{M}$ at $310 \mathrm{~K})$ was added to fixed amount of $[\mathrm{Pd}(\mathrm{Bu}-\mathrm{dtc})(\mathrm{phen})] \mathrm{NO}_{3}$ $(15 \mu \mathrm{M})$ in Tris-HCl buffer of $\mathrm{pH}$ 7.0. Change in the absorbance of $\mathrm{Pd}$ (II) complex, $\Delta \mathrm{A}$, at $300 \mathrm{~nm}$ was calculated by subtracting the absorbance reading of each DNA-metal complex solution from absorbance reading of free metal complex solution. The maximum $\Delta \mathrm{A}\left(\Delta \mathrm{A}_{\max }\right)$, i.e. change in the absorbance when all binding sites on DNA were occupied by metal complex (Fig. 2 , intercept on ordinate) is 0.246 at $300 \mathrm{~K}$ and 0.167 at $310 \mathrm{~K}$. These values were used to calculate the concentration of metal 


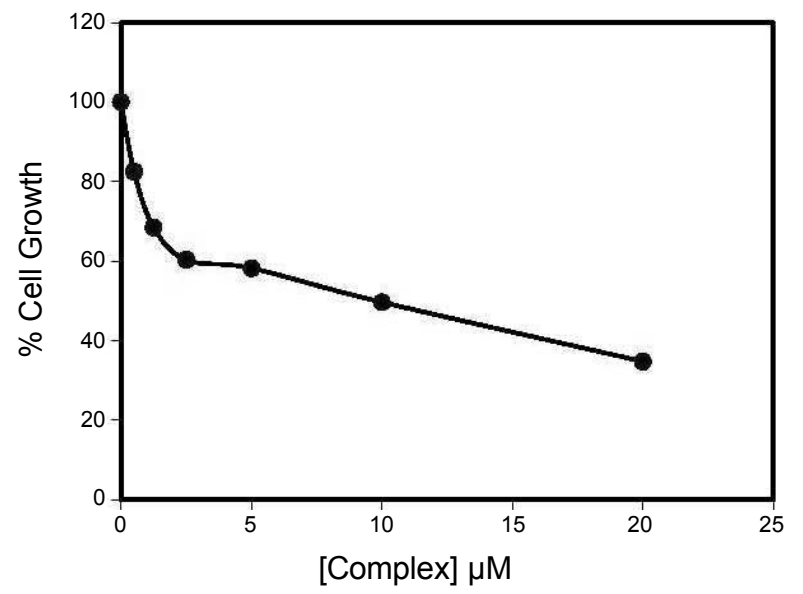

Figure 1. The growth suppression activity of the Pd(II)-complex (•) on K562 cell line was assessed using MTT assay as described in material and methods. The tumor cells were incubated with varying concentrations of the complex for $24 \mathrm{~h}$.

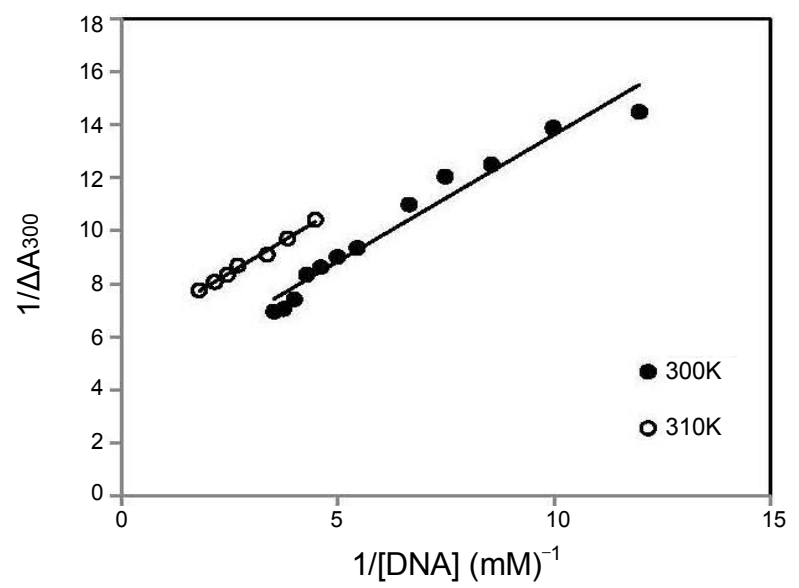

Figure 2. The changes in the absorbance of fixed amount of palladium complex in the interaction with varying amount of DNA at $300 \mathrm{~K}$ and $310 \mathrm{~K}$. The linear plot of the reciprocal of $\Delta \mathrm{A}$ versus the reciprocal of [DNA] for [Pd(Bu-dtc)(phen) $] \mathrm{NO}_{3}$.

complex bound to DNA, $[\mathrm{L}]_{b}$, and the concentration of free metal complex, $[\mathrm{L}]_{\mathrm{f}}$, and $v$, the ratio of the concentration of bound metal complex to total concentration of DNA in the next experiment ${ }^{21}$ i.e. titration of fixed amount of DNA (37.2 $\mu \mathrm{M}$ ) with varying concentration of $\mathrm{Pd}(\mathrm{II})$ complex (2.5 to $\sim 14$ $\mu \mathrm{M})$. The Scatchard plots were obtained separately at $300 \mathrm{~K}$ and $310 \mathrm{~K}$ by plotting $v /[\mathrm{L}]_{\mathrm{f}}$ versus $v$ of the relationship $v=[\mathrm{L}]_{\mathrm{b}} /$ $[D N A]_{t}$ (Fig. 3). These plots are curvilinear concave down-

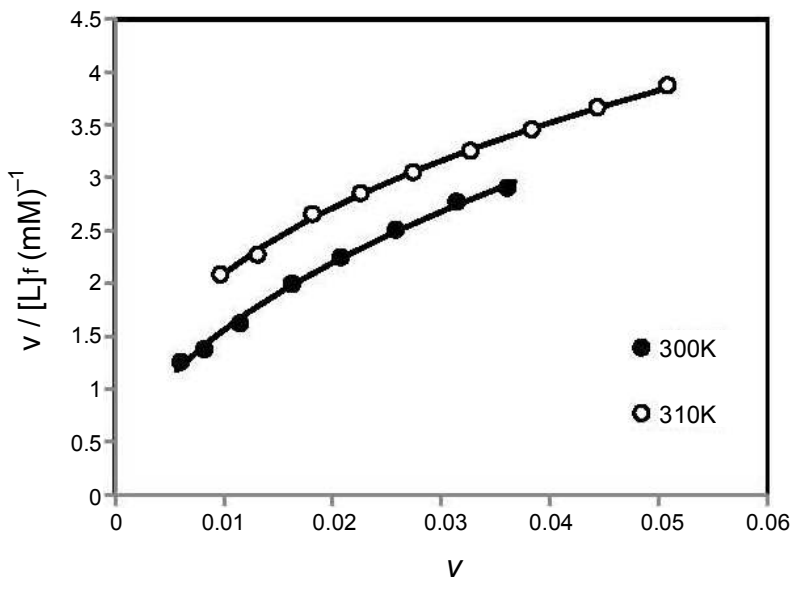

Figure 3. Scatchard plots for binding of $[\mathrm{Pd}(\mathrm{Bu}-\mathrm{dtc})(\mathrm{phen})] \mathrm{NO}_{3}$ with DNA.

wards, suggesting cooperative binding. ${ }^{31}$ Similar cooperativitity in binding of analogous complexes with DNA have also been observed. $^{22,32}$

When substituting these data $\left(v\right.$ and $\left.[\mathrm{L}]_{\mathrm{f}}\right)$ in Hill equation, $v=$ $g\left(K[L]_{f}\right)^{n} /\left(1+\left(K[L]_{f}\right)^{n}\right.$, we get a series of equations with unknown binding parameters $\mathrm{n}, \mathrm{K}$ and g. Using Eureka software, the theoretical values of these parameters have been deduced. The results are shown in Table 1. These results are comparable with those of 2,2'-bipyridine-platinum and -palladium complexes of dithiocarbamates as reported earlier. ${ }^{22,33}$ The maximum errors between experimental and theoretical values of $v$ are also shown in Table 1, which are quite low. The $\mathrm{K}$, apparent binding constant and $\mathrm{n}$, the Hill coefficient in the interaction of $[\mathrm{Pd}(\mathrm{Bu}-\mathrm{dtc})(\mathrm{phen})] \mathrm{NO}_{3}$ with DNA is higher than that of $[\mathrm{Pd}$ (Bu-dtc)(bpy)] $\mathrm{NO}_{3}{ }^{22}$ and [Pd(mor-dtc)(bpy)] $\mathrm{NO}_{3}{ }^{23}$ with DNA. This indicates that the cooperativity of phen complex to DNA is comparable with those of 2,2'-bipyridine-platinum and -palladium complexes of dithiocarbamates as reported earlier. ${ }^{22} \mathrm{Si}-$ milar results were obtained for $[\mathrm{Pd}(\mathrm{ddtc})(\mathrm{bpy})] \mathrm{NO}_{3} \cdot \mathrm{H}_{2} \mathrm{O}{ }^{33}$

Knowing the experimental (dots) and theoretical (lines) values of $v$ in the Scatchard plots and their superimposability on each other, these values of $v$ were plotted versus the values of $\ln [\mathrm{L}] \mathrm{f}$. The results are sigmoidal curves and are shown in Fig. 4 at $300 \mathrm{~K}$ and $310 \mathrm{~K}$. These plots indicate positive cooperative binding at both temperatures for the complex. The area under these plots of binding isotherms were found and by using $\mathrm{Wy}$ man-Jones equation, ${ }^{34} \mathrm{~K}_{\text {app }}, \Delta G^{\mathrm{o}}$ and $\Delta H^{\mathrm{o}}$ b were calculated at $300 \mathrm{~K}$ and $310 \mathrm{~K}$ for each particular $v$. Plots of the values of $\Delta H^{\circ} \mathrm{b}$ versus the values of $[\mathrm{L}]_{\mathrm{f}}$ are shown in Fig. 5 for $[\mathrm{Pd}(\mathrm{Bu}-\mathrm{dtc})$ (phen) $\mathrm{NO}_{3}$ at $300 \mathrm{~K}$. This plot shows that at very low value of

Table 1. Values of $\Delta \mathrm{A}_{\max }$ and binding parameters in the Hill equation for interaction between $\mathrm{Pd}(\mathrm{II})$ complex and DNA in $10 \mathrm{mmol} / \mathrm{L}$ Tris-HCl buffer and $\mathrm{pH} 7.0$

\begin{tabular}{ccccccc}
\hline Compound & Temperature $(\mathrm{K})$ & $\Delta \mathrm{A}_{\max }{ }^{a}$ & $\mathrm{~g}^{b}$ & $\mathrm{~K}^{c}(\mathrm{~mol} / \mathrm{L})^{-1}$ & $\mathrm{n}^{d}$ & Error $^{e}$ \\
\hline$\left[\mathrm{Pd}(\mathrm{Bu}-\mathrm{dtc})(\mathrm{phen}) \mathrm{NO}_{3}\right.$ & 300 & 0.246 & 5 & 6.693 & 1.972 & 0.0007 \\
& 310 & 0.167 & 5 & 4.360 & 1.604 & 0.0004 \\
\hline
\end{tabular}

$\overline{{ }^{a} \text { Change in the absorbance when all the binding sites on DNA were occupied by metal complex. }{ }^{b} \text { The number of binding sites per } 1000 \text { nucleotides. }{ }^{c} \text { The }}$ apparent binding constant. ${ }^{d}$ The Hill coefficient (as a criterion of cooperativity). ${ }^{e}$ Maximum error between theoretical and experimental values of $v$. 


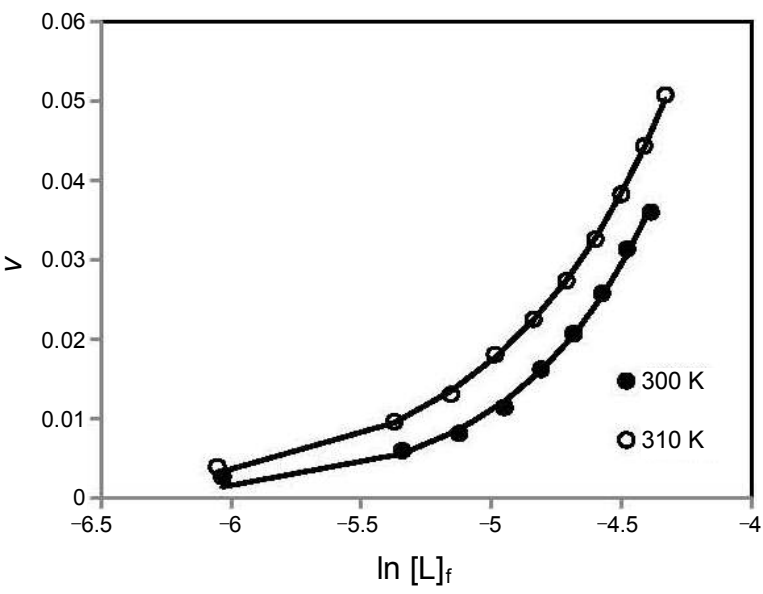

Figure 4. Binding isotherm plots for $[\mathrm{Pd}(\mathrm{Bu}-\mathrm{dtc})(\mathrm{phen})] \mathrm{NO}_{3}$ in the interaction with DNA.

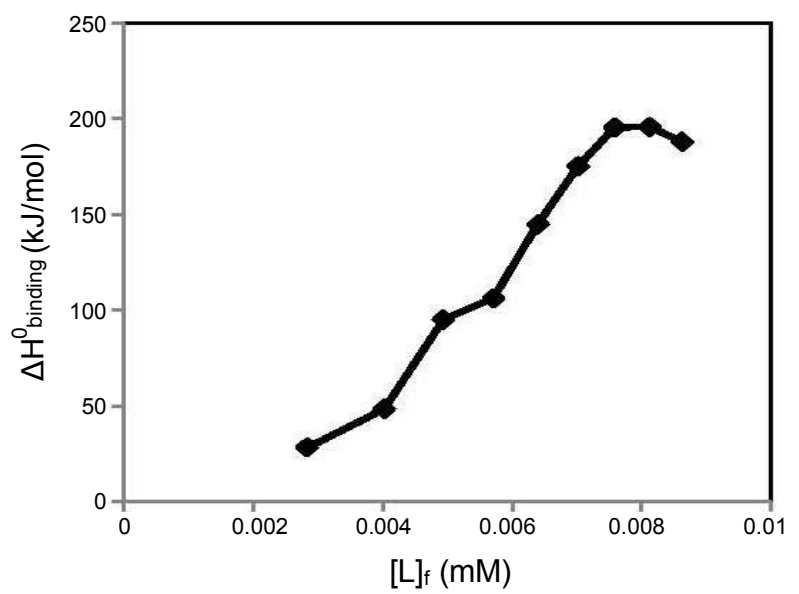

Figure 5. Molar enthalpies of binding in the interaction between DNA and $[\mathrm{Pd}(\mathrm{Bu}-\mathrm{dtc})(\mathrm{phen})] \mathrm{NO}_{3}$ versus free concentrations of complex at $\mathrm{pH} 7.0$ and $300 \mathrm{~K}$.

$[\mathrm{L}]_{\mathrm{f}}(\sim 0.0076-0.008 \mathrm{mM})$, the binding sites on DNA for Pd (II) complex have been saturated. This may be due to high affinity of Pd(II) complex with CT-DNA. ${ }^{34,35}$

DNA denaturation studies and determination of thermodynamic parameters. The procedure followed was similar to that reported earlier. ${ }^{22}$ These experiments were carried out separately at two temperatures of $300 \mathrm{~K}$ and $310 \mathrm{~K}$ in Tris- $\mathrm{HCl}$ buffer medium. The absorbance at $258 \mathrm{~nm}$ was monitored for either CTDNA $(105.30 \mu \mathrm{M}$ for experiments carried out at $300 \mathrm{~K}$ and $102.12 \mu \mathrm{M}$ at $310 \mathrm{~K}$ ) or mixtures of DNA with increasing concentrations of $\mathrm{Pd}$ (II) complex (1.35 to $25 \mu \mathrm{M}$ at $300 \mathrm{~K}$ and 0.685

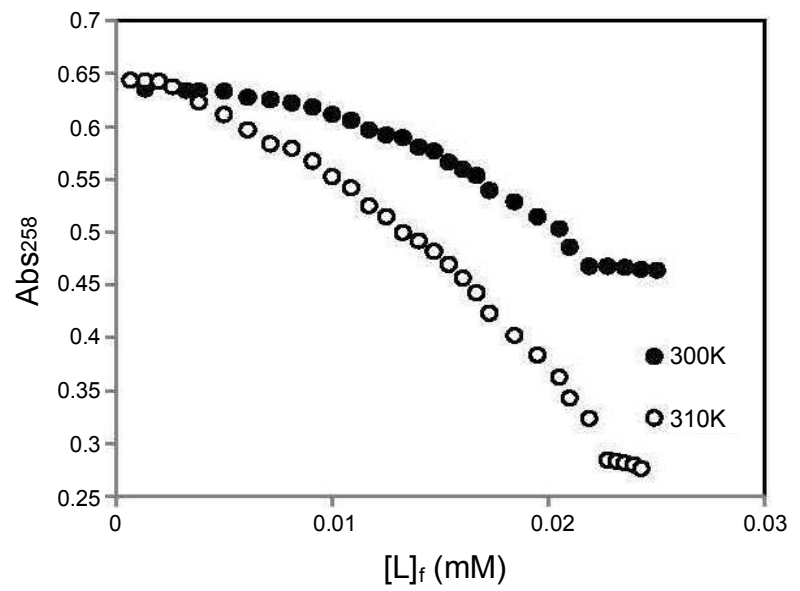

Figure 6. The changes of absorbance of DNA at $\lambda_{\max }=258 \mathrm{~nm}$ due to increasing the total concentration of $\left[\mathrm{Pd}(\mathrm{Bu}-\mathrm{dtc})(\mathrm{phen}) \mathrm{NO}_{3},[\mathrm{~L}]_{\mathrm{t}}\right.$, at constant temperature of $300 \mathrm{~K}$ and $310 \mathrm{~K}$.

to $24 \mu \mathrm{M}$ at $310 \mathrm{~K}$ ). Also the absorbance of DNA and mixture of DNA-Pd(II) complex were measured at $640 \mathrm{~nm}$ to eliminate the interference of turbidity.

The profiles of denaturation of DNA by [Pd(Bu-dtc)(phen)] $\mathrm{NO}_{3}$ are shown in Fig. 6. As the Fig. 6 shows, the concentration of metal complex in the midpoint of transition, $[\mathrm{L}]_{1 / 2}$, at $300 \mathrm{~K}$ is $13.4 \mu \mathrm{M}$ and at $310 \mathrm{~K}$ is $12.7 \mu \mathrm{M}$. One of the most important observations made in this research is the extraordinary low values of $[\mathrm{L}]_{1 / 2}$ for $[\mathrm{Pd}(\mathrm{Bu}-\mathrm{dtc})($ phen $)] \mathrm{NO}_{3}$ complex. This means that the complex can denature CT-DNA at extremely low concentration and if it will be used as anticancer agent, quite low doses will be needed, which may have fewer side effects. These values are quite lower than $[\mathrm{L}]_{1 / 2}$ values of binding of $[\mathrm{Pt} / \mathrm{Pd}$ (bpy)(Et-dtc) $] \mathrm{NO}_{3}{ }^{21}$ and $\left[\mathrm{Pt} / \mathrm{Pd}(\mathrm{bpy})(\mathrm{Bu}-\mathrm{dtc}) \mathrm{NO}_{3}{ }^{22}\right.$ complexes $(\sim 100 \mu \mathrm{M})$ with CT-DNA.

It is noticeable that, absorbance of DNA bases (purines and pyrimidines) decrease as their ring systems become parallel and near to one another, more stacking. Thus decrease in the absorbance at $258 \mathrm{~nm}$ with increase of amount of $\mathrm{Pd}$ (II) complex added to DNA may be due to: (i) a possibility that interaction between DNA and the metal complex causes the double helix of DNA to become more straight leading to stacking. This stacking may cause conformational changes leading to a sort of denaturation, or (ii) each strand after denaturation get associated in a more stacked structure and (iii) metal complex slips into the helix and masks the hydrophobic bases leading to a decrease in absorbance. As will be seen in the later part of this paper, the $[\mathrm{Pd}(\mathrm{Bu}-\mathrm{dtc})($ phen $)] \mathrm{NO}_{3}$ complex can bind CT-DNA taking the mode of intercalation. This mode of binding supports the above three hypothesis.

Table 2. Thermodynamic parameters of DNA denaturation by palladium (II) complex

\begin{tabular}{cccccc}
\hline Compound & Temperature $(\mathrm{K})$ & $\mathrm{m}^{a}(\mathrm{~kJ} / \mathrm{mol})(\mathrm{mmol} / \mathrm{L})^{-1}$ & $\Delta G_{\left(\mathrm{H}_{2} O\right)}^{\mathrm{b}}(\mathrm{kJ} / \mathrm{molK})$ & $\Delta H_{\left(\mathrm{H}_{2} \mathrm{O}\right)}^{\mathrm{c}}(\mathrm{kJ} / \mathrm{molK})$ & $\Delta S^{\mathrm{o}}{ }_{\left(\mathrm{H}_{2} \mathrm{O}\right)}{ }^{d}(\mathrm{~kJ} / \mathrm{molK})$ \\
\hline$[\mathrm{Pd}(\mathrm{Bu}-\mathrm{dtc})(\mathrm{phen})] \mathrm{NO}_{3}$ & 300 & 589.6 & 9.846 & 37.58 & 0.055 \\
& 310 & 710.1 & 19.610 & 0.030
\end{tabular}

${ }^{a}$ Measure of the metal complex ability to denature DNA. ${ }^{b}$ Conformational stability of DNA in the absence of metal complex. ${ }^{c}$ The heat needed for DNA denaturation in the absence of metal complex. ${ }^{d}$ The entropy of DNA denaturation by metal complex. 


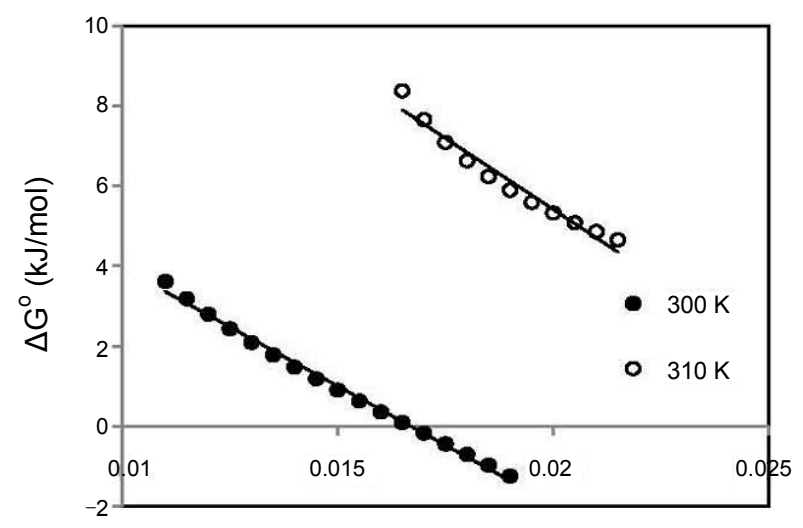

$[\mathrm{L}]_{\mathrm{t}}(\mathrm{mM})$

Figure 7. The molar Gibbs free energies plots of unfolding $\left(\Delta G^{\mathrm{o}} v s\right.$. $\left.[\mathrm{L}]_{\mathrm{t}}\right)$ of DNA in the presence of $[\mathrm{Pd}(\mathrm{Bu}-\mathrm{dtc})(\mathrm{phen})] \mathrm{NO}_{3}$.

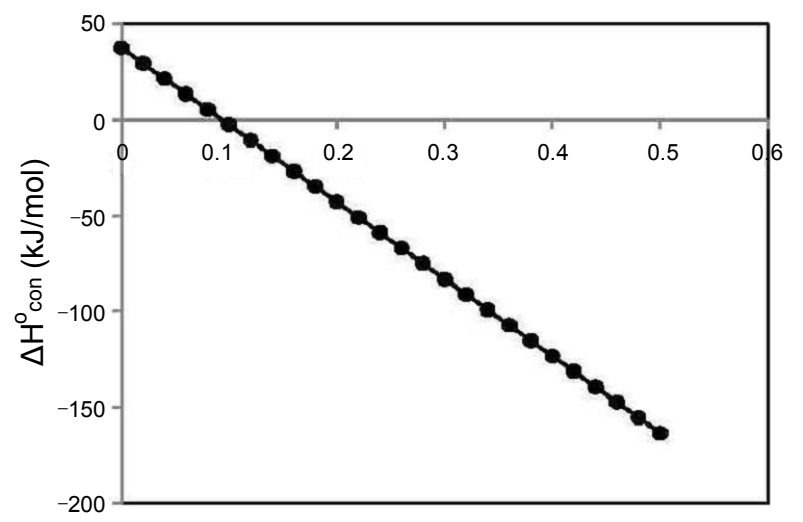

$[\mathrm{L}]_{\mathrm{t}}(\mathrm{mM})$

Figure 8. Plots of the molar enthalpies of DNA denaturation in the interaction with $[\mathrm{Pd}(\mathrm{Bu}-\mathrm{dtc})($ phen $)] \mathrm{NO}_{3}$ complex in the range of $300 \mathrm{~K}$ to $310 \mathrm{~K}$

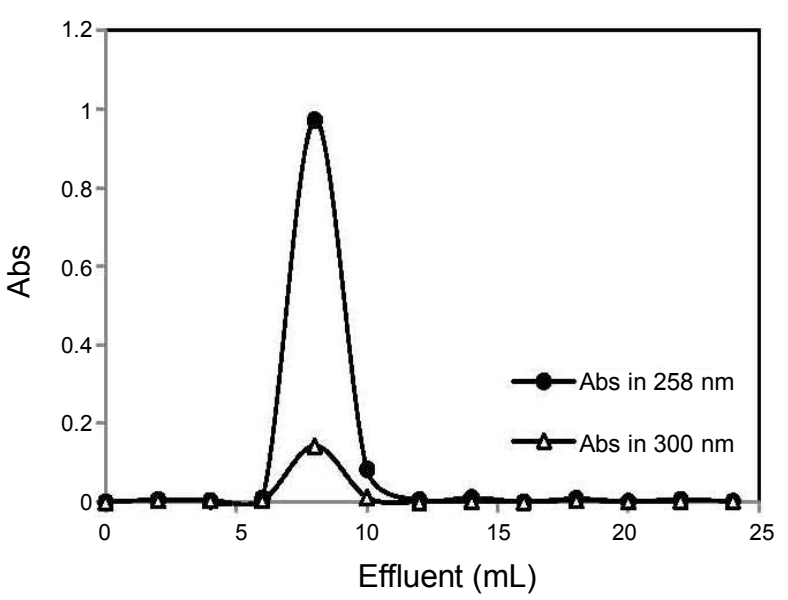

Figure 9. Gel chromatograms of $[\mathrm{Pd}(\mathrm{Bu}-\mathrm{dtc})(\mathrm{phen})] \mathrm{NO}_{3}{ }^{-} \mathrm{DNA}$ complex, obtained on Sephadex G-25 column.

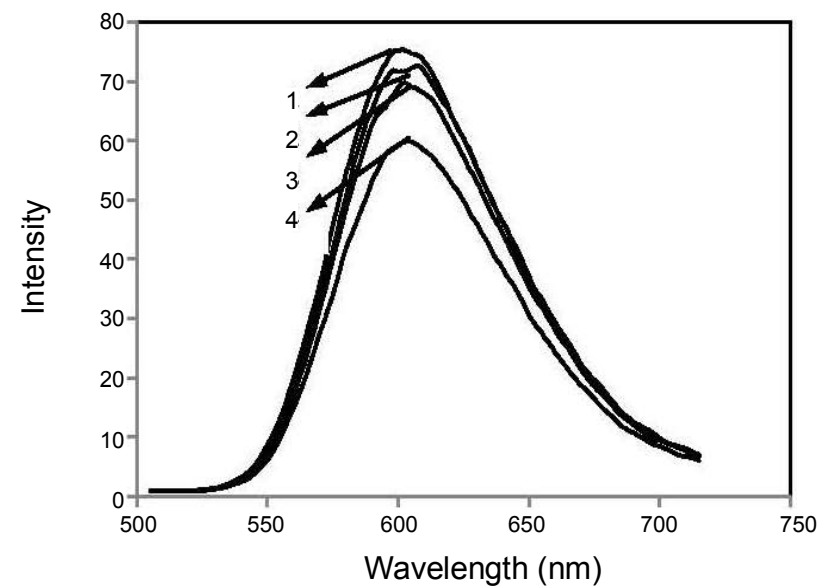

Figure 10. Fluorescence emission spectra of interacted EBr-DNA in the absence (1) and presence of different concentrations of $\mathrm{Pd}(\mathrm{II})$ complex: $8 \mu \mathrm{M}(2) ; 12 \mu \mathrm{M}(3) ; 15 \mu \mathrm{M}(4)$ at $300 \mathrm{~K}$.

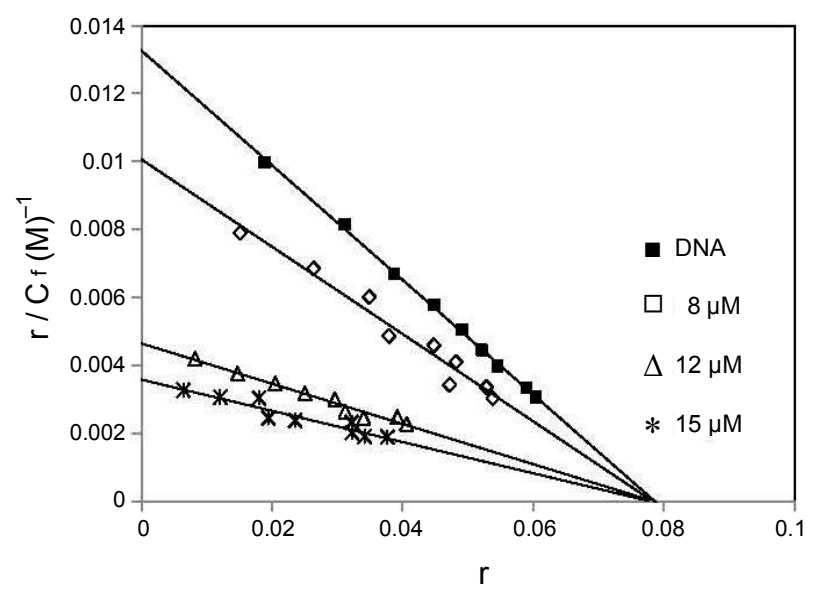

Figure 11. Competition between $[\mathrm{Pd}(\mathrm{Bu}-\mathrm{dtc})(\mathrm{phen})] \mathrm{NO}_{3}$ with ethidium bromide for the binding sites of DNA (Scatchard plot). In curve $1(\square)$, Scatchard's plot was obtained with calf thymus DNA alone. Its concentration was $60 \mu \mathrm{M}$. In curves nos. $2(\square), 3(\Delta)$ and $4(*)$ respectively, 8,12 and $15 \mu \mathrm{M}$ metal complex, were added, corresponding to molar ratio [complex]/[DNA] of $0.133,0.2$ and 0.25 . Solutions were in $10 \mathrm{mM} \mathrm{NaCl}, 10 \mathrm{mM}$ Tris- $\mathrm{HCl}(\mathrm{pH}$ 7.0). Experiments were done at room temperature.

Using the DNA denaturation plots (Fig. 6) and Pace method, ${ }^{36}$ the value of $\mathrm{K}$, unfolding equilibrium constant and $\Delta G^{\mathrm{o}}$, unfolding free energy of DNA at two temperatures of $300 \mathrm{~K}$ and at 310 $\mathrm{K}$ in the presence of $[\mathrm{Pd}(\mathrm{Bu}-\mathrm{dtc})(\mathrm{phen})] \mathrm{NO}_{3}$ have been calculated. A straight line is observed when the values of $\Delta G^{\circ}$ are plotted versus the concentration of metal complex in the transition region at $300 \mathrm{~K}$ and $310 \mathrm{~K}$. These plots are shown in Fig. 7. The $\mathrm{m}$, slope of these plots (a measure of the metal complex ability to denature DNA) and the intercept on ordinate, $\Delta G_{\left({ }_{2} O\right) \text {, }}^{0}$ (conformational stability of DNA in the absence of metal complex) are summarized in Table 2. The values of $m$ for the above complex are much higher than those of $\mathrm{Pd}(\mathrm{II})$ complexes reported earlier, ${ }^{21,22}$ which indicate the higher ability of this Pd(II) complex to denature DNA. As we know, the higher the 
values of $\Delta G^{\mathrm{o}}$, the larger the conformational stability of DNA. However, the values of $\Delta G^{\mathrm{o}}$ (Table 2) are increased by increasing the temperature. This is as expected because in general, most of the macromolecules are more stable at higher values of $\Delta G^{0}{ }_{\left(\mathrm{H}_{2} \mathrm{O}\right)}{ }^{37}$ Molar enthalpy of DNA denaturation in absence of $\mathrm{Pd}(\mathrm{II})$ complex, $\Delta H^{\mathrm{o}}{ }_{\left(\mathrm{H}_{2} \mathrm{O}\right)}$, is another important thermodynamic parameter. To find this, we calculated the molar enthalpy of DNA denaturation in presence of the metal complex, $\Delta H_{\text {conformation or }}^{\circ}$

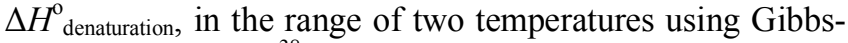
Helmholtz equation. ${ }^{38}$ On ploting the values of these enthalpies versus the concentration of metal complex, straight line will be obtained which are shown in Fig. 8 for $[\mathrm{Pd}(\mathrm{Bu}-\mathrm{dtc})(\mathrm{phen})]$ $\mathrm{NO}_{3}$ complex. Intrapolation of these lines (intercept on ordinate, i.e., absence of metal complex) gives the values of $\Delta H^{0}{ }_{\left(\mathrm{H}_{2} \mathrm{O}\right)}$ (Table 2). This plot shows that in the rang of $300-310 \mathrm{~K}$ the changes in the enthalpies in presence of $\mathrm{Pd}(\mathrm{II})$ complex are descending. These observations indicate that on increasing the concentration of $\mathrm{Pd}$ (II) complex, the stability of DNA is decreased. Moreover, the entropy of DNA unfolding by $\operatorname{Pd}(\mathrm{II})$ complex, $\Delta S_{\left(\mathrm{H}_{2} \mathrm{O}\right)}^{\mathrm{C}}$ have been calculated using equation $\Delta G=\Delta H$-T $\Delta S$ and the data are given in Table 2. These data show that the metalDNA complex is more disordered than that of native DNA, because the entropy changes are positive for $\mathrm{Pd}(\mathrm{II})$-DNA complex in the denaturation processes of CT-DNA (Table 2). The above thermodynamic parameters agree well with those we have reported for [Pt/Pd(bpy)(Et-dtc) $] \mathrm{NO}_{3}{ }^{21}$ and $[\mathrm{Pt} / \mathrm{Pd}(\mathrm{bpy})(\mathrm{Bu}-\mathrm{dtc})]$ $\mathrm{NO}_{3}{ }^{22}$ complexes.

Modes of binding. CT-DNA $(5.07 \mu \mathrm{M})$ was interacted with $\left[\mathrm{Pd}(\mathrm{Bu}-\mathrm{dtc})(\right.$ phen $) \mathrm{NO}_{3}(47.5 \mu \mathrm{M})$ for $6 \mathrm{~h}$ at $300 \mathrm{~K}$ in Tris- $\mathrm{HCl}$ buffer. This DNA-metal complex solution was then passed through a Sephadex G-25 column equilibrated with the same buffer. The elusion of the column fractions of $2.0 \mathrm{~mL}$ was monitored at $300 \mathrm{~nm}$ and $258 \mathrm{~nm}$ for DNA-Pd(II) complex system. These results are given in Fig. 9. This plot shows that the peak obtained for the two wavelengths are not resolved and suggests that DNA has not separated from the metal complex. Thus it implies that the binding between DNA and the metal complex is not reversible under such circumstances. Because, if the interaction between DNA and metal complex was weak, the DNA should have come out of the column separately. ${ }^{39}$

The interaction between DNA and the Pd(II) complex was further investigated by precipitation of DNA from interacted DNA-metal complex with excess ethanol, where the metal complex was not found in the supernatant as observed by spectral method. It suggests that the bonding of this metal complex with DNA is strong enough and does not break readily. It is also irreversible and supported the above experiment. ${ }^{39}$

Thermal denaturation of CT-DNA in presence and absence of the above mentioned Pd(II) complex were conducted. In this experiment, an incubated DNA-metal complex solution was subjected to denaturation achieved by heating at $100{ }^{\circ} \mathrm{C}$ for 10 min. same concentrations of DNA and metal complex solutions were separately run as blank. Spectral changes were measured immediately at $300 \mathrm{~nm}$ for $\mathrm{Pd}(\mathrm{II})$ complex and at $258 \mathrm{~nm}$ for DNA solutions at about $0{ }^{\circ} \mathrm{C}$. There is a $84-86 \%$ reduction in binding of denatured DNA to $\mathrm{Pd}(\mathrm{II})$ complex as compared with binding of native DNA to the same compound. This implies that denatured DNA also has some favorable binding sites (other than intercalation) for the above metal complex. . $^{41}$

Another study to determine the character of the interaction between $\mathrm{Pd}$ (II) complex and CT-DNA was done as described earlier. ${ }^{33}$ Increasing ionic strengths of the medium $(50 \mathrm{mM} \mathrm{NaCl}$ and $0.6 \mathrm{mM} \mathrm{MgCl}_{2}$ ) reversed the binding by $12 \%$ and $14 \%$ respectively. This shows that electrostatic or hydrogen bonding or both may have been involved in the binding of above cationic palladium(II) complex with CT-DNA. However, as the percentage of reversal in binding is low, some other interactions must be also involved in the binding.

Ethidium bromide (EBr) displacement experiments. In order to establish the binding of $\left[\mathrm{Pd}(\mathrm{Bu}-\mathrm{dtc})(\mathrm{phen}) \mathrm{NO}_{3}\right.$ to DNA by intercalation, the ethidium bromide $(\mathrm{EBr})$ solution prepared in the above buffer of $\mathrm{pH} 7.0$ was titrated with DNA-palladium complex in the same buffer. Fig. 10 shows the effect of $\mathrm{Pd}(\mathrm{II})$ complex $(8,12$ and $15 \mu \mathrm{M})$ on fluorescence spectrum of solution containing CT-DNA $(60 \mu \mathrm{M})$ and $\operatorname{EBr}(2 \mu \mathrm{M})$. It is seen that increasing the concentration of the $\mathrm{Pd}$ (II) complex results in a gradual decrease in fluorescence intensity of CT-DNA-EBr solution, without affecting any perceptible shifts in fluorescence $\lambda_{\max }$. This implies that the Pd(II) complex can displace $\mathrm{EBr}$ from DNA-EBr system. A similar fluorescence quenching behavior was observed for analogous Pd(II) complexes reported earlier. $^{21,22}$

Other studies to determine the character of the above interaction was done as described earlier. ${ }^{23}$ It is well known that the fluorescence of ethidium bromide is greatly enhanced upon nonspecifically intercalation into DNA. However, competitive binding of the $\mathrm{Pd}(\mathrm{II})$ complex and $\mathrm{EBr}$ to DNA will result in a decrease in the fluorescence intensity. The number of EBr molecules intercalated to DNA in presence of different concentrations of the Pd(II) complex was calculated using Scatchard analysis. ${ }^{42}$ In this experiment, the wavelengths of excitation and emission were set at $540 \mathrm{~nm}$ and $700 \mathrm{~nm}$ respectively with both having $0.5 \mathrm{~nm}$ slit widths. Solutions of DNA, EBr and metal complex were prepared in Tris- $\mathrm{HCl}$ buffer of $\mathrm{pH}$ 7.0. In this medium, $\mathrm{Pd}$ (II) complex were interacted with CT-DNA by incubating them at $300 \mathrm{~K}$ for $6 \mathrm{~h}$, appropriate amount of $\mathrm{EBr}$ was added to them and further incubated at room temperature $(300 \mathrm{~K})$ for $6 \mathrm{~h}$ and finally processed for fluorescence spectral

Table 3. Binding parameters for the effect of palladium complex on the fluorescence of $\mathrm{EBr}$ in the presence of DNA

\begin{tabular}{ccccc}
\hline \multirow{2}{*}{ Compound } & \multicolumn{3}{c}{$\mathrm{r}_{\mathrm{f}}^{a}$} \\
\cline { 2 - 5 } & 0.00 & 0.133 & 0.20 & 0.25 \\
\hline$\left[\mathrm{Pd}(\mathrm{Bu}-\mathrm{dtc})(\mathrm{phen}) \mathrm{NO}_{3}\right.$ & $0.168^{b}(0.078)^{c}$ & $0.128(0.078)$ & $0.059(0.078)$ & $0.045(0.078)$ \\
\hline
\end{tabular}

${ }^{a}$ Formal ratio of metal complex to nucleotide concentration. ${ }^{b}$ Association constant ${ }^{c}$ Number of binding sites (n) per nucleotide. 
measurements. Saturation curves of fluorescence intensity for $[\mathrm{Pd}(\mathrm{Bu}-\mathrm{dtc})(\mathrm{phen})]^{+}$-DNA system at different $\mathrm{r}_{\mathrm{f}}$ values $(0.133$, 0.2 and 0.25$)$ in presence of increasing concentrations of $\mathrm{EBr}$ $(2,4$ to $\ldots, 20 \mu \mathrm{M})$ were obtained. The fluorescence Scatchard plots obtained for binding of $\mathrm{EBr}$ to DNA in absence $(\bullet)$ and prescence $(O)$ of various concentration of $[\mathrm{Pd}(\mathrm{Bu}-\mathrm{dtc})(\mathrm{phen})]$ $\mathrm{NO}_{3}$ complex were shown in Fig. 11. This figure shows that the complex inhibits competitively the EBr binding to DNA (type-A behavior), where number of binding sites n, (intercept on the abscissa) remain constant and the slope of the graphs that is $\mathrm{K}_{\mathrm{app}}$, (apparent association constant) decrease with increasing the concentration of $\mathrm{Pd}(\mathrm{II})$ complex (Table 3 ). This implies that the $[\mathrm{Pd}(\mathrm{Bu}-\mathrm{dtc})(\mathrm{phen})] \mathrm{NO}_{3}$ complex is intercalating in DNA and thereby competing for intercalation sites occupied by EBr. The values of $\mathrm{K}_{\text {app }}$ and $\mathrm{n}$, are listed in Table 3 . The analogous [Pd(bpy)(mor-dtc) $] \mathrm{NO}_{3}$ and [Pt(bpy)(mor-dtc)] $\mathrm{NO}_{3}{ }^{23}$ complexes with few other Diimine/Diamine palladium(II) complexes of diethyldithiocarbamate ${ }^{33}$ showed similar modes of binding.

\section{Conclusions}

The work presented deals with the synthesis and characterization of a new palladium(II) complex bearing 1,10-phenanthroline and butyldithiocarbamate ligands. It shows in vitro cytotoxic properties about fifteen times better than cisplatin. The DNA-binding behavior of this complex was examined by absorption and fluorescence spectra. Experimental results indicate that the complex can bind to CT-DNA take the modes of intercalation and probably ionic binding. It can denature the DNA at very low concentrations. Several binding and thermodynamic parameters have been determined which may be useful to understand the mechanism of interaction of this type of compounds with DNA or their antitumor activities.

Acknowledgments. Financial assistance from the Research Council of University of Sistan and Baluchestan and of University of Tehran is gratefully acknowledged.

\section{References}

1. Nagababu, P.; Latha, J. N. L.; Rajesh, M.; Satyanarayana. S. J. Iran. Chem. Soc. 2009, 6(1), 145.

2. Metcalfe, C.; Thomas, J. A. Chem. Soc. Rev. 2003, 32, 215.

3. Hag, I.; Lincoln, P.; Suh, D.; Norden, B.; Choedhry, B. Z.; Chaires. J. B. J. Am. Chem. Soc. 1995, 117, 4788.

4. Pyle, A. M.; Rehmann, J. P.; Meshoyrer, R.; Kumar, C. V.; Turro, N. J.; Barton. J. K. J. Am. Chem. Soc. 1989, 111, 3051.

5. Catherine, H.; Marguerite, P.; Michael, R. G.; Stephanie Heinz, S.; Bernard. M. J. Biol. Inorg. Chem. 2001, 6, 14.

6. Li, V. S.; Choi, D.; Wang, Z.; Jimenez, L. S.; Tang, M. S.; Kohn, H. J. Am. Chem. Soc. 1996, 118, 2326.

7. Zuber, G.; Quada Jr., J. C.; Hecht, S. M. J. Am. Chem. Soc. 1998, $120,9368$.

8. Erkkila, K. E.; Odom, D. T.; Barton, J. K. Chem. Rev. 1999, 99, 30077.

9. Sadler, P. J. Adv. Inorg. Chem. 1991, 39, 1.
10. Guo, Z.; Sadler, P. J. Angew. Chem. Int. Ed. 1999, 38, 1512.

11. Martinez, A.; Lorenzo, J.; Prieto, M. J.; Font-Bardia, M.; Solans, X.; Aviles, F. X.; Moreno, V. Bioorg. Med. Chem. 2007, 15, 969.

12. Faraglia, G.; Fregona, D.; Sitran, S.; Giovagnini, L.; Marzano, C.; Baccichetti, F.; Casellato, U.; Graziani, R. J. Inorg. Biochem. 2001, 83, 31 .

13. Zipp, A. P.; Zipp, S. G. J. Chem. Educ. 1977, 54, 739.

14. Borch, R. F.; Bodenner, D. L.; Katz, J. C.; Hacker, P. M.; Douple, E. B.; Krakoff, I. H. Platinum coordination compounds in cancer chemotherapy; Martinus Nijhoff: Boston, 1984; p 154.

15. Manav, N.; Mishra, A. K.; Kaushik, N. K. Spectrochim. Acta part A 2004, 60, 3087.

16. Fregona, D.; Giovagnini, L.; Ronconi, L.; Marzano, C.; Trevisan, A.; Sitran, S.; Biondi, B.; Bordin, F. J. Inorg. Biochem. 2003, 93, 181.

17. Manav, N.; Mishra, A. K.; Kaushik. N. K. Spectrochim. Acta. 2006, 65,32 .

18. Blake, A. J.; Kathirgamanathan, P.; Toohey, M. J. Inorg. Chim. Acta. 2000, 303, 1310.

19. Shaheen, F.; Badshah, A.; Gielen, M.; Dusek, M.; Fejfarova, K.; de Vos, D.; Mirza, B. J. Organomet. Chem. 2007, 692, 3019.

20. Siddiqi, K. S.; Nami, S. A. A.; Ghebude, L and Y. J. Braz. Chem. Soc. 2006, 17(1), 107.

21. Islami-Moghaddam, M.; Mansouri-Torshizi, H.; Divsalar, A.; Saboury. A. A. J. Iran. Chem. Soc. 2009, 6(3), 552.

22. Mansouri-Torshizi, H.; I-Moghaddam, M.; Divsalar, A.; Saboury, A. A. Bioorg. Med. Chem. 2008, 16, 9616 .

23. Mansouri-Torshizi, H.; I-Moghaddam, M.; Divsalar, A.; Sabour. A. A. J. Biomol. Struct dyn. 2009, 26(5), 575.

24. Ronconi; L.; Giovagnini; L.; Marzano, C.; Bettio, F.; Ganziani; R.; Pilloni, G.; Fregona, D. Inorg. Chem. 2005, 44, 1867.

25. Manohar, A.; Ramalingam, K.; Bocelli, G.; Righi, L. Inorg. Chem. Acta. 2001, 314, 177.

26. Song, X. Q.; Wang, Y. W.; Zheng, J. R.; Liu, W. S.; Tan, M. Y. Spectrochim. Acta. Part A 2007, 68, 701.

27. Geary, W. J. Coord. Chem. Rev. 1971, 7, 81.

28. Divsalar, A.; Saboury, A. A.; Yousefi, R.; Moosavi-Movahedi, A. A.; Mansouri-Torshizi, H. Int. J. Biol. Macro. 2007, 40, 381.

29. King, A. M. Q.; Nicholson, B. H. Biochem. J. 1969, 114, 679.

30. Kumar, L.; Kandasamy, N. R.; Srivastava, T. S.; Amonkar, A. J.; Adwankar, M. K.; Chitnis. M. P. J. Inorg. Biochem. 1985, 23, 1.

31. Saboury. A. A. J. Iran. Chem. Soc. 2006, 3(1), 1.

32. Bhadra, K.; Maiti, M.; Kumar, G. S. Biochim. et Biophys. Acta. 2007, 1770, 1071.

33. Mital, R.; Jain, N.; Srivastava, T. S. Inorg. Chim. Acta. 1989, 166, 135 .

34. Mansouri-Torshizi, H.; I-Moghaddam, M.; Saboury, A. A. Acta Biochim.et Biophys. Sin. 2003, 35, 886.

35. Saboury, A. A.; Shamsaei, A. A.; Moosavi-movahedi, A. A.; Mansouri- Torshizi, H. J. Chin. Chem. Soc. 1999, 46, 917.

36. Greene, R. F.; Pace, C. N. J. Biol. Chem. 1974, 249, 5388.

37. Bathaie, S. Z.; Bolhasani, A.; Hoshyar, R.; Ranjbar, B.; Sabouni, F.; Moosavi-Movahedi, A. A. J. DNA and Cell Biology 2007, 26, 533.

38. Barrow, G. M. In Physical Chemistry; $5^{\text {th }}$ ed.; Graw-Hill, MC: New York, 1988; Chap. 7.

39. Mansouri-Torshizi, H.; Mital, R.; Srivastava, T. S.; Parekh, H.; Chitnis, M. P. J. Inorg. Biochem. 1991, 44, 239.

40. Mansouri-Torshizi, H.; Srivastava, T. S.; Chavan, S. J.; Chitinis, M. P. J. Inorg. Biochem. 1992, 48, 63.

41. Christian, A. M.; Constantinos, E. D.; Christodoulos, M. Inorg. Chim. Acta 2008, 361, 1973.

42. Scatchard. G. Ann. N. Y. Acad Sci. 1949, 51, 660. 